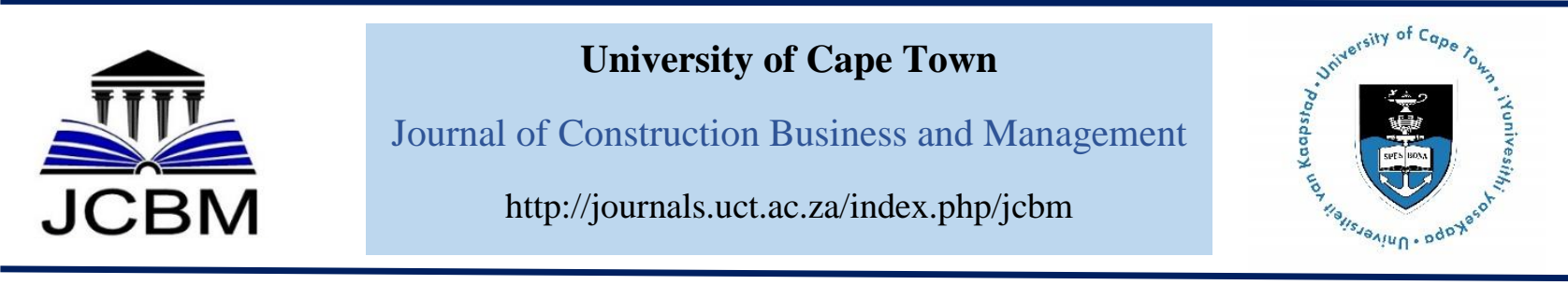

\title{
Causes of Errors in Construction Contract Documents in Southwestern, Nigeria
}

\author{
O S. Dosumu ${ }^{1}$, G. I. Idoro ${ }^{2}$, H. N. Onukwube ${ }^{3}$ \\ Department of Building, University of Lagos, Nigeria ${ }^{1,2,3}$
}

Received 2 November 2016; received in revised form 20 February 2017; accepted 29 March 2017

\begin{abstract}
The issue of continual poor project performance in the construction industry remains unresolved, and there is the need for improvement. In view of improving project performance, this study aims at investigating the frequent causes of errors in construction contract documents. A mixed method (questionnaire survey and interview) research approach was used for the study. The respondents for the study (selected with two-stage stratified - random sampling technique) consist of 86 consulting and 98 contracting firms that have been engaged in building projects that have more than one floor between 2012 and 2015. Fifty-one (51) interviews were also conducted with contractors, project managers and consultants on the projects they were involved on and that provided further necessary information for the study. The tools that were used for the analysis of this study include descriptive (sums, frequency and percentages) and inferential (t-test) statistics. The study found that the causes of errors in contract documents comprise of frequent design changes by clients, lack of adequate time to prepare documents and design management experience among others. Based on the findings, it was concluded that the causes of errors in contract documents vary from one state to the other. It was also found that there is a difference in the causes of errors in contract documents based on types of building, services rendered by construction organisations and states in South West, Nigeria. However, there is no significant difference in the causes of errors in contract documents based on procurement method except where there is incomplete documentation or contracting organisations have overlapping activities. The study recommended that the errors identified should always be prevented from occurring if cost and time overrun are to be minimized. Also since most of the causes identified are related to consultants, it was recommended that all designs should go through quality assurance process.
\end{abstract}

Keywords: Building Projects, Construction, Contract documents, Errors, Project performance.

\section{Introduction}

Poor project performance remains an unsolved problem in the construction industry, and its occurrence has continually led to the frustration of many clients (Love et al. 2011). It has also led to profit marginalization for contractors, disputes, loss of confidence and reputation for consultants and eventual discouragement of investments in construction projects. Many factors have been traced to poor project performance (mostly measured in terms of cost, time and quality) but notable among them are errors in construction contract documents. To substantiate the gravity of mistakes in contract documents, Okuntade (2014) affirmed that errors in contract documents account for more than $82 \%$ of all construction errors committed. Ade-Ojo and Babalola (2013) and Mukaka et al. (2014) also noted that errors in contract documents are the major factors affecting the cost and time performance of building projects.

About eighty-seven (87) causes of errors were attributed to errors in contract documents, some of which include lack of consistency (Norman 1983), unreliable and incompetent staff and acceptance of low design fee (Love et al. 2011) among others. The problem is that many of the studies reported in the literature on errors in contract documents are not empirical aside being conducted outside Nigeria; thereby making it difficult to determine the frequency of occurrence of the causes of

\footnotetext{
${ }^{1}$ Corresponding Author. Tel: +234 8173291721

Email address: osdosumu@ unilag.edu.ng

${ }^{2}$ Email address: iroidoro@yahoo.co.uk

${ }^{3}$ Email address: onukwube12345678@yahoo.com
} 
errors in contract documents of construction projects. Without an assessment of the frequent causes of errors in contract documents, it may be difficult to know the errors that need urgent tackling. The effects of such errors on project performance may also be difficult to curtail.

The situation is worse in Nigeria because, despite identifying that errors in contract documents are among the leading causes of poor project performance, studies revealing the causes of errors in contract documents are very scarce. Babalola and Idehen (2011), Olaniyan (2011) and Okuntade (2014) clearly stated that errors in contract documents, design errors and omissions are the major reasons construction projects are plagued with disputes, wastes, variation, project abandonment, and profit marginalization for contractors, loss of confidence and reputation for consultants and eventual discouragement of investment in construction projects among others. AdeOjo and Babalola (2013) also noted that errors in contract documents are the reasons for the non-completion of construction projects on time (or abandoned), to cost and quality. What remains unsolved in these studies, however, are the causes of the errors in contract documents that contribute to the identified problems.

From the literature reviewed, there appear to be limited empirical studies on the frequent causes of errors in contract documents. Therefore, there is need to conduct an empirical study with regards to the frequent causes of errors in contract documents because of the important effects they can have on projects and stakeholders. Without a study of this nature, the achievement of successful project performance may be a mirage in the construction industry.

\section{Literature Review}

It is not only consultants' errors that affect construction project performance; construction errors also take its toll on it. However, this study concentrates on errors in construction contract documents (consultants' errors) because it seems not to be a popular subject of discussion by Nigerian authors and it also appears to be a major area of error in the construction industry that adversely affects project performance in any country. This was substantiated by Mohammed (2007) who noted that project consultants play a major role in project cost overrun due to errors in contract documents.

The research carried out in Australia reveals that ninety-two percent $(92 \%)$ of the variation in their construction industry were attributable to errors in contract documents and the consultants' team share $60 \%$ of the variation (Choy \& Sidwell 1991). Diekman and Nelson (1985) also noted that the largest proportion of change orders and modifications originate from the owner (client) or their representatives (consultants) and these account for $46 \%$ of claims in federally funded projects. The study conducted by Burati et al. (1992) on nine fasttrack industrial construction projects show that while construction deviations average $16 \%$ of the total number of deviations, design deviations averaged $78 \%$ of the total number of deviations. Hence, the need to determine the frequency of the causes of errors in contract documents on building projects.
Some of the causes linked to errors in contract documents by various researchers in the construction industry include lack of consistency (Norman, 1983), reuse of notes and details of similar projects, wrong assumptions of standard practice, inexperience, lack of clarity and poor interface co-ordination, poor management practices, inadequate quality management, poor communication, absence of well-defined design leadership, unclear project leadership role and lack of design verifications (Palaneeswaran, et al. 2007). Low design fees, clients' briefs, quality control, design time allowances, constructability, quality of staff (Tilley, et al. 2005), unreliable and incompetent staff, acceptance of low design fee (Love et al. 2011), time boxing (Love et al. 2000), planning/programming, stress, repetitive tasks (Shelton, 1999), limited attention, biases, modification of rules (Cheng-Wing \& Davey 1998), unavailable data, memory loss, misperception of data, over-reliance on default values and failure to monitor data (Endsley 1999) are other causes of errors in contract documents.

Barkow (2005) identified negligence, lack of adequate design references, and lack of knowledge, poor teamwork, human error, inadequate design checks, poor communications and complexity of task as causes of errors in contract documents. Contradiction of information, untried new technologies, adaptation of technology to human beings, physical and mental conditions (Vrouwenvelder et al. 2009), extra works, delays/disruption, conflicts, incompatibility /inconsistency, omission, inadequate detail/description, insufficient legibility (Long, 2011), motivation, cooperation, (Love \& Josephson 2004), carelessness, lack of diligence, ineffective use of computer aided design, unrealistic client demands, low task awareness, overload, fatigue, lack of knowledge of changes in standards and not knowing what is required (Love, et al. 2008) are other causes of consultants' errors. Ortega and Bisgaard (2000) concluded that the causes of errors are engineers and architects inexperience in design and unplanned inspection in contract documents. Tzortzopoulos and Formoso (1999) noted that the causes of errors in construction contract documents are poor communication, lack of adequate documentation, deficient or missing input information, unbalanced resource allocation, lack of coordination between disciplines, erratic decision making, lack of technology and incorrect application of existing knowledge. Other causes of errors pointed out were poor design quality, lack of design standards, lack of constructability of designs, defects of individual specialists, changes introduced by owners and designers, inconsistencies between drawings and specifications, designer with little construction knowledge, non-technical specifications (Alarcon \& Mardones 1998), deficient procedures, poor communication between workers, inadequately trained workers, conflicting interest of workers, inadequately labelled equipment and poorly designed equipment (Rooney, et al., 2002).

As a result of the enormity of these causes Mohammed (2007) classified them into management - related causes, consultant - related causes, client - related causes, project characters and industry-related causes. Atkinson (1998) categorized them into primary causes (e.g. selfinspection, education/training), managerial causes (e.g. 
delegation of duties, change controlling, concurrent working control, communications) and global causes (e.g. organizational culture, economic pressure, time pressure, political pressure and societal pressure). Barkow (2005) classified them into technical, organizational and management errors. Yates and Lockley (2002) categorized the causes of errors into the design, construction, material, administrative and maintenance errors. The categorization of Love et al. (2009) was practice, task, circumstance, task, organization, system, industry and tool. Cheng-wing and Davey (1998) classified errors into the design, environmental and personnel causes.

From the literature reviewed so far, it appears that the causes of errors in contract documents vary from one country to the other, hence their enormity warrant categorization. Therefore, there is the need to conduct a similar study on the subject to determine the frequent causes of errors in Nigerian contract documents. Dosumu and Iyagba (2013) appraised the factors responsible for errors in construction documents using construction professionals and contractors in Lagos State, Nigeria. The deficiency in the study is that aside responses being based on the general perception of respondents rather than specific projects; the study was based on Lagos state alone. The same procedure is evident in Dosumu and Adenuga (2013) when the causes, effects and remedies of errors in Nigerian construction documents were investigated. It is, therefore, inappropriate to state that the results of the studies are representative of any geopolitical zones in Nigeria not to talk of representing the nation at large. Lagos state is only one out of the thirty-six states in Nigeria. Therefore, a detailed study of the breakdown of causes of errors in contract documents that can be representative of a wider area of Nigeria is required and that is why this study is focusing on a wider area of Southwestern Nigeria.

\section{Research Method}

This study adopted the mixed (questionnaire survey and interview) method research approach. The research area is South Western, Nigeria. Before the movement of the capital of Nigeria to Abuja, Lagos has thrived as the capital city and the economic hub of the country. During that period, many organizations including those in the construction sector had their head offices in Lagos or neighbouring states. Therefore, for this study, the research area is South-West, Nigeria.

Table 1: Population and Sample Size of the Study
The population of this study consists of contracting and consulting firms in Southwest, Nigeria that was engaged in building projects between 2012 and 2015 . Consultants' opinions were required because they prepare the contract documents of construction projects. The views of contractors were required because they make use of the documents prepared by consultants and they discover the errors in them. Years between 2012 and 2015 were selected to ensure that projects used for the study are recent. The list of contracting firms is collated from the Federation of Construction Industry (FOCI) and states tender boards of the six states in Southwest, Nigeria. There were situations where companies appeared in both sources; a unified list was, therefore, prepared to take care of repeatedly listed firms. Hence, 275 contracting firms were collated from the six states in the geopolitical zone. The consulting firms used for this study are those that were collected from the directories of professional/regulatory bodies which include the Architect Registration Council of Nigeria/Nigerian Institute of Architects (ARCON/NIA), Council of Registered Builders of Nigeria/Nigerian Institute of Building (CORBON/NIOB), Quantity Surveyors Registration Board of Nigeria/ Nigerian Institute of Quantity Surveyors (QSRBN/NIQS) and the Council for the Regulation of Engineering/Nigerian Society of Engineers (COREN/NSE). Hence, the consulting firms used for this study are 128 Building firms, 399 Engineering firms, 136 Quantity Surveying companies and 323 Architectural firms respectively and this brings the total number of consulting firms for this study to 986 . The population for this study is 275 building contractors and 986 construction consultants.

The study adopts the formula proposed by the Creative Research System (2001) in calculating the sample size. Thus:

$S S=\frac{Z^{2} \times P \times(1-P)}{C^{2}}$

Where: $S S=$ Sample size, $Z=Z$-value at $95 \%$ confidence level (1.96), $P=$ probability of selecting a population member (0.5), $C=$ Margin of error at $95 \%$ confidence level (0.05)

Using the formula, the sample size for contracting firms is 161, and that of consulting firms is 275 (36 Building, 103 Engineering, 46 Quantity Surveying and 90 Architectural firms). Hence, the two-stage stratified random sampling technique was used for this study.

\begin{tabular}{|c|c|c|c|c|c|c|c|c|c|c|}
\hline \multirow{3}{*}{ Location of project } & \multirow{2}{*}{\multicolumn{2}{|c|}{$\begin{array}{l}\text { Contracting } \\
\text { firms }\end{array}$}} & \multicolumn{8}{|c|}{ Consulting firms } \\
\hline & & & \multicolumn{2}{|c|}{ Architects } & \multicolumn{2}{|c|}{ Builders } & \multicolumn{2}{|c|}{ Engineers } & \multicolumn{2}{|c|}{ Qty. Surv. } \\
\hline & POP & SS & POP & SS & POP & SS & POP & SS & POP & SS \\
\hline Lagos & 122 & 71 & 120 & 33 & 70 & 20 & 148 & 41 & 54 & 15 \\
\hline Ogun & 61 & 36 & 46 & 13 & 23 & 6 & 71 & 20 & 32 & 9 \\
\hline Oyo & 32 & 19 & 46 & 13 & 16 & 5 & 49 & 14 & 23 & 6 \\
\hline Osun & 25 & 15 & 44 & 12 & 11 & 3 & 35 & 10 & 22 & 6 \\
\hline Ekiti & 14 & 8 & 36 & 10 & - & - & 36 & 10 & 17 & 5 \\
\hline Ondo & 21 & 12 & 31 & 9 & 8 & 2 & 30 & 8 & 18 & 5 \\
\hline Total & 275 & 161 & 323 & 90 & 128 & 36 & 369 & 103 & 166 & 46 \\
\hline
\end{tabular}

$P O P=$ Population, $S S=$ Sample Size, Qty. Surv = Quantity Surveyors 
The first stratum was the division of respondents into consulting and contracting firms. The second stage involved stratifying consultants into architectural, building, engineering and quantity surveying firms. Table 1 shows population and sample size distribution of the study.Fifty-one (51) interviews were also conducted with contractors, project managers and consultants on the projects they were involved and can equally identify the causes of errors in the contract documents of such projects. The selection of 51 interviewees was based on the experience, willingness of the experts to be interviewed and execution of the type of projects investigated in this study.

\section{Data Presentation and Analysis}

The questionnaire for the study was administered on 436 respondents across the South-West part of Nigeria, and only 184 of them were completed, and this gives a response rate of $42.2 \%$. Table 2 shows the details of projects investigated during the interview. A total of $60.8 \%$ were executed with traditional procurement method, 29.4\% with design and build method and 9.8\% adopted the management method. Also, $96.1 \%$ of the projects have architectural drawings, $90.2 \%$ have structural drawings, $80.4 \%$ have M\&E drawings, $90.2 \%$ have bills of quantities, $51 \%$ have specifications, $86.3 \%$ have conditions of the contract and $47.1 \%$ have other documents.

The $51 \%$ reported for the availability of specifications represent material and job specifications. Also, the interview reveals that some specifications are attachments to drawings; however it was gathered that such specifications lack details and precision. Despite the large percentages recorded for most contract documents, it is surprising to find out that some building projects were commenced with only letters of the award. An interviewee noted that he began the construction of a semi-detached twin duplex at Millennium Estate, Lekki Phase II with just the client's brief. Another interviewee commenced a hotel suite at Port-Harcourt with just the conditions of contract, approximate estimate and trade preambles (specifications). A total of $47.1 \%$ of the respondents noted that they had other contract documents at the time they were moving to site. Some of the other contract documents include schedule of day work rates, article of agreement, deeds of agreement, soil geotechnical report, program of work, survey plan, letter of award, total quality management plan, bank/ insurance bond, health and safety plan, form of tender, allocation letter, method statement, appendices and trade preambles.

Table 2: Details of Projects Investigated During Interview

\begin{tabular}{|c|c|c|}
\hline Details of projects & Frequency & Percentage $(\%)$ \\
\hline \multicolumn{3}{|l|}{ Procurement Method } \\
\hline Traditional & 31 & 60.8 \\
\hline Design and build & 15 & 29.4 \\
\hline Management (project \& management contracting) & 5 & 9.8 \\
\hline Total & 51 & 100.0 \\
\hline \multicolumn{3}{|c|}{ Available contract document (more than one was ticked) } \\
\hline Architectural drawing & 49 & 96.1 \\
\hline Structural drawing & 46 & 90.2 \\
\hline Mechanical \& Electrical drawing & 41 & 80.4 \\
\hline Bill of quantities & 46 & 90.2 \\
\hline Specification & 26 & 51.0 \\
\hline Condition of contract & 44 & 86.3 \\
\hline Other documents & 24 & 47.1 \\
\hline
\end{tabular}

The distribution of respondents according to profession, sector of project involvement, work experience and educational qualification is depicted in Table 3.

Table 3: General Information of Respondents, Organisations and Investigated Building Projects

\begin{tabular}{|c|c|c|c|c|c|c|}
\hline \multirow{2}{*}{ Respondents' information } & \multicolumn{2}{|c|}{ Consultant } & \multicolumn{2}{|c|}{ Contractor } & \multicolumn{2}{|c|}{ Total } \\
\hline & Number & $\%$ & Number & $\%$ & Number & $\%$ \\
\hline \multicolumn{7}{|l|}{ Profession of respondents } \\
\hline Architecture & 15 & 17.4 & 17 & 17.3 & 32 & 17.4 \\
\hline Civil/Structural engineering & 16 & 18.6 & 20 & 20.4 & 36 & 19.6 \\
\hline Quantity surveying & 30 & 34.9 & 26 & 26.5 & 56 & 30.4 \\
\hline Building & 15 & 17.4 & 28 & 28.6 & 43 & 23.4 \\
\hline Electrical/Mechanical engineering & 10 & 11.7 & 7 & 7.2 & 17 & 9.2 \\
\hline \multicolumn{7}{|l|}{ Sector of project investigated } \\
\hline Public & 43 & 50.0 & 49 & 50.0 & 92 & 50.0 \\
\hline Private & 43 & 50.0 & 49 & 50.0 & 92 & 50.0 \\
\hline
\end{tabular}




\begin{tabular}{|c|c|c|c|c|c|c|}
\hline \multicolumn{7}{|c|}{ Work experience of respondents } \\
\hline $1-5$ years & 17 & 19.8 & 32 & 32.7 & 49 & 26.6 \\
\hline $6-10$ years & 35 & 40.6 & 45 & 45.9 & 80 & 43.5 \\
\hline $11-15$ years & 22 & 25.6 & 13 & 13.3 & 35 & 19.0 \\
\hline $16-20$ years & 12 & 14.0 & 8 & 8.1 & 20 & 10.9 \\
\hline \multicolumn{7}{|c|}{ Educational qualification } \\
\hline OND & 3 & 3.5 & 2 & 2.0 & 5 & 2.7 \\
\hline HND/B.Sc. & 55 & 64.0 & 84 & 85.7 & 139 & 75.5 \\
\hline M.Sc. & 28 & 32.5 & 11 & 11.3 & 39 & 21.2 \\
\hline Ph.D. & 0 & 0.0 & 1 & 1.0 & 1 & 0.5 \\
\hline \multicolumn{7}{|c|}{ Type of building project } \\
\hline Residential & 40 & 46.5 & 48 & 49.0 & 88 & 47.8 \\
\hline Institutional & 20 & 23.3 & 17 & 17.3 & 37 & 20.1 \\
\hline Religious & 2 & 2.3 & 2 & 2.0 & 4 & 2.2 \\
\hline Commercial & 24 & 27.9 & 31 & 31.7 & 55 & 29.9 \\
\hline \multicolumn{7}{|l|}{ Location of project } \\
\hline Lagos state & 44 & 51.2 & 37 & 37.8 & 81 & 44.0 \\
\hline Ogun state & 17 & 19.8 & 19 & 19.4 & 36 & 19.6 \\
\hline Oyo state & 20 & 23.2 & 12 & 12.2 & 32 & 17.4 \\
\hline Osun state & 3 & 3.5 & 10 & 10.2 & 13 & 7.1 \\
\hline Ondo state & 0 & 0.0 & 12 & 12.2 & 12 & 6.5 \\
\hline Ekiti state & 2 & 2.3 & 8 & 8.2 & 10 & 5.4 \\
\hline \multicolumn{7}{|l|}{ Procurement method } \\
\hline Traditional & 13 & 15.1 & 18 & 18.4 & 31 & 16.8 \\
\hline Design and build & 26 & 30.2 & 40 & 40.8 & 66 & 35.9 \\
\hline Management method & 47 & 54.7 & 40 & 40.8 & 87 & 47.3 \\
\hline \multicolumn{7}{|l|}{ Type of construction } \\
\hline New & 82 & 95.3 & 89 & 90.8 & 171 & 92.9 \\
\hline Refurbishment & 4 & 4.7 & 9 & 9.2 & 13 & 7.1 \\
\hline Total & 86 & 100.0 & 98 & 100.0 & 184 & 100.0 \\
\hline
\end{tabular}

From Table 3, it is evident that the respondents and their organizations are qualified to give useful information for the study. Table 3 also indicates the general information of the building projects used for this study. The information includes the type of project, location, procurement method and type of construction. Most of the projects used for this study are new works and residential in nature. Also, Lagos state constitutes the supplier of the largest building projects (44\%), followed by Ogun (19\%) and Oyo state $(17.4 \%)$ respectively. It is interesting to know that the traditional method of procurement is the least used on the projects used for this study

Table 4 presents the frequency of occurrence of the causes of errors in contract documents.

Table 4: Causes of Errors in Contract Documents According to Services Rendered and Their Test of Difference

\begin{tabular}{|c|c|c|c|c|c|c|}
\hline Causes of errors & $\begin{array}{l}\text { Cons. } \\
\text { Mean }\end{array}$ & $\begin{array}{l}\text { Contr. } \\
\text { Mean }\end{array}$ & $\begin{array}{l}\text { Total } \\
\text { Mean }\end{array}$ & $\begin{array}{c}\mathbf{P} \\
\text { Value }\end{array}$ & Significance & Decision \\
\hline Design management experience & $4.18(1)$ & $3.73(1)$ & $3.94(1)$ & 0.024 & Significant & Reject $\mathrm{H}_{\mathrm{o}}$ \\
\hline Project brief & $3.88(3)$ & $3.54(5)$ & $3.70(2)$ & 0.059 & N. significant & Accept $\mathrm{H}_{\mathrm{o}}$ \\
\hline Designer professional education & $3.92(2)$ & $3.50(6)$ & $3.70(3)$ & 0.019 & Significant & Reject Ho \\
\hline Lack of design standards & $3.79(5)$ & 3.57 (3) & $3.67(4)$ & 0.263 & N. significant & Accept $\mathrm{H}_{\mathrm{o}}$ \\
\hline $\begin{array}{l}\text { Poor communication among project } \\
\text { participants }\end{array}$ & $3.73(7)$ & $3.55(4)$ & $3.63(5)$ & 0.429 & N. significant & Accept $\mathrm{H}_{\mathrm{o}}$ \\
\hline Lack of coordination between disciplines & $3.60(15)$ & $3.61(2)$ & $3.61(6)$ & 0.924 & N. significant & Accept $\mathrm{H}_{\mathrm{o}}$ \\
\hline Management organizational structure & $3.72(8)$ & $3.49(7)$ & $3.60(7)$ & 0.237 & N. significant & Accept $\mathrm{H}_{\mathrm{o}}$ \\
\hline $\begin{array}{l}\text { Lack of consistency between drawing and } \\
\text { specification }\end{array}$ & $3.85(4)$ & $3.35(14)$ & $3.59(8)$ & 0.017 & Significant & Reject $\mathrm{H}_{\mathrm{o}}$ \\
\hline Carelessness and negligence & $3.67(10)$ & $3.45(8)$ & $3.55(9)$ & 0.271 & N. significant & Accept $\mathrm{H}_{\mathrm{o}}$ \\
\hline Insufficient fund to create quality documents & $3.72(8)$ & $3.36(1$ & 3.53( & 0.076 & ificant & \\
\hline Errors in design assumptions/calculations & $3.77(6)$ & $3.27(23)$ & $3.51(11)$ & 0.016 & Significant & Reject $\mathrm{H}_{\mathrm{o}}$ \\
\hline $\begin{array}{l}\text { Availability and contradictions of design } \\
\text { information }\end{array}$ & $3.65(12)$ & 3.36(11) & $3.50(12)$ & 0.102 & N. significant & Accept $\mathrm{H}_{\mathrm{o}}$ \\
\hline Physical and mental conditions & $3.66(11)$ & $3.34(16)$ & $3.49(13)$ & 0.073 & N. significant & Accept $\mathrm{H}_{\mathrm{o}}$ \\
\hline Lack of awareness of changes in standards & $3.65(12)$ & $3.34(16)$ & $3.48(14)$ & 0.108 & N. significant & Accept $\mathrm{H}_{\mathrm{o}}$ \\
\hline Inadequate documentation & $3.58(28)$ & $3.36(11)$ & $3.47(15)$ & 0.198 & N. significant & Accept $\mathrm{H}_{\mathrm{o}}$ \\
\hline Complexity of design and project & $3.59(17)$ & $3.35(14)$ & $3.46(16)$ & 0.274 & N. significant & Accept $\mathrm{H}_{\mathrm{o}}$ \\
\hline
\end{tabular}




\begin{tabular}{|c|c|c|c|c|c|c|}
\hline Identification of project risk & $3.60(15)$ & $3.31(19)$ & $3.45(17)$ & 0.612 & N. significant & Accept $\mathrm{H}_{\mathrm{o}}$ \\
\hline Inadequate design time & $3.43(27)$ & $3.41(9)$ & $3.42(18)$ & 0.917 & N. significant & Accept $\mathrm{H}_{\mathrm{o}}$ \\
\hline Lack of motivation & $.65(12)$ & $3.14(29)$ & $3.37(19)$ & 0.004 & Significant & Reject $\mathrm{H}_{\mathrm{o}}$ \\
\hline Procurement process & $55(19)$ & $3.20(26)$ & $3.37(20)$ & 0.062 & N. significant & Accept $\mathrm{H}_{\mathrm{o}}$ \\
\hline Unrealistic client demand & 40(30) & $3.32(18)$ & $3.36(21)$ & 0.660 & N. significant & Accept $\mathrm{H}_{\mathrm{O}}$ \\
\hline Lack of planning and inspection of project & 49(22) & $3.22(22)$ & $3.35(22)$ & 0.109 & N. significant & Accept $\mathrm{H}$ \\
\hline Nature of economy & $51(20)$ & $3.20(26)$ & $3.35(23)$ & 0.096 & N. significant & $A$ cont $U$ \\
\hline Attitude of client & $3.38(31)$ & $3.29(20)$ & 3.34(24) & 0.612 & N. Significant & Accept $\mathrm{H}_{\mathrm{o}}$ \\
\hline $\begin{array}{l}\text { Transfer of knowledge and experience } \\
\text { between designers }\end{array}$ & $3.36(33)$ & $3.29(20)$ & $3.32(25)$ & 0.685 & N. significant & $\Delta$ ccent $\mathrm{K}$ \\
\hline Completeness/contradiction of information & $3.51(20)$ & $3.14(29)$ & $3.31(26)$ & 0.028 & Significant & Reject $\mathrm{H}$ \\
\hline $\begin{array}{l}\text { Unclear and ambiguous requirements for } \\
\text { design specifications }\end{array}$ & $3.37(32)$ & $3.26(24)$ & $3.31(27)$ & 0.518 & N. significant & Accept \\
\hline broval & $3.47(26)$ & $3.16(28)$ & $3.31(28)$ & 0.154 & N. significant & Accept \\
\hline Projec & $3.31(38)$ & $3.28(22)$ & $3.29(29)$ & 0.846 & ficant & Accept $\mathrm{H}$ \\
\hline $\begin{array}{l}\text { Standard of university education in contract } \\
\text { courses }\end{array}$ & $3.43(27)$ & $3.41(9)$ & $3.28(30)$ & 0.103 & N. significant & Accept \\
\hline at nature of industry & $3.41(29)$ & $3.13(32)$ & $3.26(31)$ & 0.078 & N. significant & Accent \\
\hline & & & & & & \\
\hline & & & & 0.276 & & \\
\hline & & & & 0.013 & & \\
\hline and finish time & & $2.99(37)$ & & 0.008 & & $\mathrm{t} \mathrm{H}_{\mathrm{o}}$ \\
\hline & & & & & & \\
\hline & & & & & N. si & \\
\hline & & & & & & \\
\hline oroanizations & & $2.90(41)$ & & 0.944 & N. significant & Accept I \\
\hline & $.32(36)$ & $2.88(44)$ & $3.09(40)$ & 0.023 & Significant & Reject $\mathrm{H}$ \\
\hline certificate of insurance & $3.02(43)$ & $3.08(36)$ & $3.06(41)$ & 0.744 & N. significant & Accept 1 \\
\hline Type of & & & & & & \\
\hline & $3.11(42)$ & 2.93(39) & $3.01(43)$ & 0.301 & N. significant & Accept 1 \\
\hline $\begin{array}{l}\text { Re-use of notes and details of similar } \\
\text { projects }\end{array}$ & $2.78(42)$ & $2.92(40)$ & $2.86(44)$ & 0.472 & N. significant & Accept l \\
\hline & & & & & & \\
\hline & $3.31(38)$ & & $3.29(29)$ & 0.846 & N. significant & Accent \\
\hline $\begin{array}{l}\text { Standard of university education in contract } \\
\text { courses }\end{array}$ & $3.43(27)$ & $3.41(9)$ & $3.28(30)$ & 0.103 & N. significant & tespes \\
\hline & & & & & & \\
\hline Uniqueness of project & $3.35(34)$ & $3.13(32)$ & $3.23(32)$ & 0.289 & N. significant & $\Delta$ ccent \\
\hline
\end{tabular}

Cons $=$ Consultant, Cont $=$ Contractor,$<0.05=$ Significant, therefore Reject Ho

According to the consultants, the frequent causes of errors include design management experience (4.18), designer professional education (3.92), project brief (3.88), lack of consistency between drawings and specifications (3.85), lack of design standards (3.79) and among others. The ratings of the contractors are design management experience (3.73), lack of coordination among disciplines (3.61), lack of design standards (3.57), poor communication among project participants (3.55) and project brief (3.54). The two sets of respondents (contractors and consultants) unanimously agreed that the top causes of errors in contract documents are design management experience (3.94), project brief (3.70), designer professional education (3.70), lack of design standards (3.67) and poor communication among project participants (3.63) to mention a few.

Table 4 also tests the difference in the responses of consultants and contractors on the causes of errors in contract documents. This hypothesis was tested with the independent samples t-test and it was found that from the 44 causes of errors investigated, there are significant differences in the causes of errors in contract documents between the consultants and contractors (that is the null hypothesis was rejected, and the alternative was accepted) on eleven (11) of them. Hence, there is a significant difference in the perception of consultants and contractors to causes of error in contract documents in the aspect of design management experience, designer professional education and amount of work with design organizations. This result was not unexpected because consultants and contractors protect different interests on every project and as such, they are bound to vary on issues that conflict their interests. For instance, while contractors would claim that designers have little experience of designing, designers on the hand will blame poor design on inadequate project brief. The result is also consistent with the findings of Mohammed (2007) and Norman (1983). However, re-use of notes and details of similar project, types of client and acceptance of low fees were highly rated as significant by Palaneeswaran et al. (2007), Tilley et al. (2005) and Love et al. (2011) but this result shows that they are not frequent causes of errors in contract documents. Table 5 shows the mean values of the errors in contract documents according to the types of building projects investigated. 
Table 5: Causes of Errors in Contract Documents According to Type of Building Projects and Their Test of Difference

\begin{tabular}{|c|c|c|c|c|c|c|c|c|}
\hline Causes of errors & $\begin{array}{l}\text { Resi. } \\
\text { Mean }\end{array}$ & $\begin{array}{l}\text { Insti. } \\
\text { Mean }\end{array}$ & $\begin{array}{l}\text { Relig. } \\
\text { Mean }\end{array}$ & $\begin{array}{l}\text { Comm. } \\
\text { Mean }\end{array}$ & $\begin{array}{l}\text { Total } \\
\text { Mean }\end{array}$ & $\begin{array}{c}\mathbf{P} \\
\text { value }\end{array}$ & Sig. & Decision \\
\hline Design management experience & 3.79 & 4.31 & 3.50 & 3.96 & 3.94 & 0.241 & N.S & Accept \\
\hline Project brief & 3.53 & 4.16 & 4.25 & 3.62 & 3.70 & 0.042 & $\mathrm{~S}$ & Reject \\
\hline Designer professional education & 3.68 & 3.76 & 4.00 & 3.66 & 3.70 & 0.938 & S & Reject \\
\hline Lack of design standards & 3.36 & 4.22 & 4.00 & 3.75 & 3.67 & 0.006 & $\mathrm{~S}$ & Reject \\
\hline $\begin{array}{l}\text { Poor communication among project } \\
\text { participants }\end{array}$ & 3.51 & 4.03 & 3.75 & 3.57 & 3.63 & 0.372 & N.S & Accept \\
\hline Lack of coordination between disciplines & 3.44 & 4.25 & 3.25 & 3.47 & 3.61 & 0.016 & $\mathrm{~S}$ & Reject \\
\hline Management organizational structure & 3.64 & 3.59 & 3.75 & 3.53 & 3.60 & 0.963 & N.S & Accept \\
\hline $\begin{array}{l}\text { Lack of consistency between drawing and } \\
\text { specification }\end{array}$ & 3.43 & 4.00 & 3.25 & 3.60 & 3.59 & 0.221 & N.S & Accept \\
\hline Carelessness and negligence & 3.38 & 4.00 & 3.50 & 3.52 & 3.55 & 0.114 & N.S & Accept \\
\hline $\begin{array}{l}\text { Insufficient fund to create quality } \\
\text { documents }\end{array}$ & 3.47 & 3.73 & 3.50 & 3.51 & 3.53 & 0.012 & $S$ & Reject \\
\hline Errors in design assumptions/calculations & 3.24 & 4.11 & 4.00 & 3.49 & 3.51 & 0.014 & $\mathrm{~S}$ & Reject \\
\hline $\begin{array}{l}\text { Availability and contradictions of design } \\
\text { information }\end{array}$ & 3.32 & 3.65 & 4.00 & 3.64 & 3.50 & 0.274 & N.S & Accept \\
\hline Physical and mental conditions & 3.42 & 3.62 & 3.50 & 3.52 & 3.49 & 0.863 & N.S & Accept \\
\hline Lack of awareness of changes in standards & 3.34 & 3.89 & 3.50 & 3.43 & 3.48 & 0.185 & N.S & Accept \\
\hline Inadequate documentation & 3.18 & 3.84 & 3.00 & 3.69 & 3.47 & 0.008 & $\mathrm{~S}$ & Reject \\
\hline Complexity of design and project & 3.17 & 4.08 & 3.50 & 3.48 & 3.46 & 0.012 & $\mathrm{~S}$ & Reject \\
\hline Identification of project risk & 3.42 & 3.62 & 3.00 & 3.41 & 3.45 & 0.700 & N.S & Accept \\
\hline Inadequate design time & 3.31 & 3.64 & 3.33 & 3.42 & 3.42 & 0.570 & N.S & Accept \\
\hline Lack of motivation & 3.25 & 3.78 & 3.25 & 3.31 & 3.38 & 0.159 & N.S & Accept \\
\hline Procurement process & 3.19 & 3.62 & 3.25 & 3.48 & 3.37 & 0.303 & N.S & Accept \\
\hline Unrealistic client demand & 3.02 & 3.86 & 3.00 & 3.57 & 3.36 & 0.002 & $\mathrm{~S}$ & Reject \\
\hline Lack of planning and inspection of project & 3.29 & 3.41 & 3.50 & 3.38 & 3.35 & 0.947 & N.S & Accept \\
\hline Nature of economy & 3.15 & 3.62 & 4.00 & 3.43 & 3.35 & 0.162 & N.S & Accept \\
\hline Attitude of client & 3.14 & 3.92 & 3.25 & 3.25 & 3.34 & 0.008 & $\mathrm{~S}$ & Reject \\
\hline $\begin{array}{l}\text { Transfer of knowledge and experience } \\
\text { between designers }\end{array}$ & 3.27 & 3.44 & 3.75 & 3.30 & 3.32 & 0.768 & N.S & Accept \\
\hline Completeness/contradiction of information & 3.27 & 3.64 & 3.25 & 3.16 & 3.31 & 0.251 & N.S & Accept \\
\hline $\begin{array}{l}\text { Unclear and ambiguous requirements for } \\
\text { esign specifications }\end{array}$ & 3.18 & 3.47 & 3.75 & 3.38 & 3.31 & 0.425 & N.S & Accept \\
\hline Authority approval & 3.02 & 3.76 & 3.50 & 3.43 & 3.31 & 0.069 & N.S & Accept \\
\hline Project cost & 3.08 & 3.57 & 4.25 & 3.37 & 3.29 & 0.102 & N.S & Accept \\
\hline $\begin{array}{l}\text { Standard of university education in contract } \\
\text { courses }\end{array}$ & 3.22 & 3.30 & 2.75 & 3.40 & 3.28 & 0.667 & N.S & Accept \\
\hline Fragment nature of industry & 3.19 & 3.42 & 3.50 & 3.24 & 3.26 & 0.721 & N.S & Accept \\
\hline Uniqueness of project & 3.00 & 3.56 & 3.75 & 3.35 & 3.23 & 0.165 & N.S & Accept \\
\hline Low designer salary & 3.17 & 3.35 & 3.25 & 3.24 & 3.23 & 0.897 & N.S & Accept \\
\hline Size of project & 3.09 & 3.68 & 3.50 & 3.11 & 3.23 & 0.139 & N.S & Accept \\
\hline Construction start and finish time & 3.21 & 3.31 & 3.00 & 3.20 & 3.22 & 0.958 & N.S & Accept \\
\hline Lack of clarity and legibility & 3.17 & 3.35 & 4.00 & 3.00 & 3.17 & 0.399 & N.S & Accept \\
\hline Inadequate design staff & 3.18 & 3.24 & 3.25 & 3.08 & 3.16 & 0.909 & N.S & Accept \\
\hline Concurrent /overlapping activities & 3.20 & 3.28 & 3.33 & 2.92 & 3.14 & 0.411 & N.S & Accept \\
\hline Amount of work with design organizations & 3.12 & 3.16 & 3.25 & 3.02 & 3.10 & 0.948 & N.S & Accept \\
\hline Personality attitudes & 2.89 & 3.70 & 3.25 & 2.96 & 3.09 & 0.010 & $\mathrm{~S}$ & Reject \\
\hline $\begin{array}{l}\text { Non-request for certificate of insurance } \\
\text { covering design and errors }\end{array}$ & 3.05 & 2.92 & 3.00 & 3.07 & 3.06 & 0.833 & N.S & Accept \\
\hline Type of client & 2.92 & 3.25 & 3.25 & 3.02 & 3.02 & 0.668 & N.S & Accept \\
\hline Acceptance of low design fees & 2.99 & 3.08 & 3.25 & 2.98 & 3.01 & 0.947 & N.S & Accept \\
\hline $\begin{array}{l}\text { Re-use of notes and details of similar } \\
\text { projects }\end{array}$ & 2.71 & 2.97 & 3.00 & 3.00 & 2.86 & 0.561 & N.S & Accept \\
\hline
\end{tabular}

Resi=Residential, Insti=Institutional, Relig=Religious, Comm=Commercial

Table 5 also demonstrates the Analysis of Variance (ANOVA) test conducted to determine if there are differences in the perception of the respondents on the causes of errors in contract documents based on the types of building projects. Ranking among the types of building projects investigated, the factors that cause errors the most in contract documents are design management experience (3.94), project brief (3.70), designers' professional 
education (3.70), lack of design standards (3.67), poor communication among project participants (3.63) to mention a few. The descriptive statistics show that many of the causes investigated are frequently occurring. However, the ANOVA test conducted indicates that there are significant differences in eleven (11) of the forty-four (44) causes of errors in contract documents studied. This result was unexpected because it would have been thought that whatever causes an error on one type of project should be capable of doing same on other types of projects. However, justification could still be provided for the result based on the different sizes, procurement route and complexity of projects involved.

Table 6 indicates the causes of errors in contract documents according to the procurement methods investigated in this study.

Table 6: Causes of Errors in Contract Documents According to Procurement Methods and Their Test of Difference

\begin{tabular}{|c|c|c|c|c|c|c|c|}
\hline Causes of errors & Trad. & $\begin{array}{c}\text { D\&B } \\
. \\
\end{array}$ & $\begin{array}{c}\mathrm{P} / \mathrm{C} \\
\text { management }\end{array}$ & $\begin{array}{l}\text { Total } \\
\text { Mean } \\
\end{array}$ & $\begin{array}{c}\mathbf{P} \\
\text { value }\end{array}$ & Sig. & Decision \\
\hline Design management experience & 4.28 & 3.88 & 3.87 & 3.94 & 0.336 & N.S & Accept \\
\hline Project brief & 3.90 & 3.52 & 3.77 & 3.70 & 0.257 & N.S & Accept \\
\hline Designer professional education & 3,69 & 3.76 & 3.66 & 3.70 & 0.864 & N.S & Accept \\
\hline Lack of design standards & 4.03 & 3.67 & 3.55 & 3.67 & 0.203 & N.S & Accept \\
\hline Poor communication among project participants & 4.00 & 3.60 & 3.53 & 3.63 & 0.340 & N.S & Accept \\
\hline Lack of coordination between disciplines & 3.87 & 3.55 & 3.55 & 3.61 & 0.492 & N.S & Accept \\
\hline Management organizational structure & 3.71 & 3.86 & 3.36 & 3.60 & 0.054 & N.S & Accept \\
\hline Lack of consistency between drawing and specs & 4.01 & 3.50 & 3.48 & 3.59 & 0.87 & N.S & Accept \\
\hline Carelessness and negligence & 3.87 & 3.58 & 3.42 & 3.55 & 0.245 & N.S & Accept \\
\hline Insufficient fund to create quality documents & 3.84 & 3.63 & 3.36 & 3.53 & 0.187 & N.S & Accept \\
\hline Errors in design assumptions/calculations & 3.97 & 3.28 & 3.51 & 3.51 & 0.74 & N.S & Accept \\
\hline $\begin{array}{l}\text { Availability and contradictions of design } \\
\text { information }\end{array}$ & 3.39 & 3.70 & 3.40 & 3.50 & 2.56 & N.S & Accept \\
\hline Physical and mental conditions & 3.65 & 3.41 & 3.51 & 3.49 & 0.671 & N.S & Accept \\
\hline Lack of awareness of changes in standards & 3.81 & 3.57 & 3.30 & 3.48 & 0.141 & N.S & Accept \\
\hline Inadequate documentation & 3.86 & 3.11 & 3.59 & 3.47 & 0.005 & $\mathrm{~S}$ & Reject \\
\hline Complexity of design and project & 3.48 & 3.45 & 3.46 & 3.46 & 0.994 & N.S & Accept \\
\hline Identification of project risk & 3.29 & 3.41 & 3.53 & 3.45 & 0.617 & N.S & Accept \\
\hline Inadequate design time & 3.64 & 3.35 & 3.38 & 3.42 & 0.512 & N.S & Accept \\
\hline Lack of motivation & 3.61 & 3.27 & 3.27 & 3.38 & 0.430 & N.S & Accept \\
\hline Procurement process & 3.06 & 3.52 & 3.37 & 3.37 & 0.271 & N.S & Accept \\
\hline Unrealistic client demand & 3.55 & 3.17 & 3.43 & 3.36 & 0.297 & N.S & Accept \\
\hline Lack of planning and inspection of project & 3.47 & 3.44 & 3.24 & 3.35 & 0.512 & N.S & Accept \\
\hline Nature of economy & 3.29 & 3.22 & 3.46 & 3.35 & 0.504 & N.S & Accept \\
\hline Attitude of client & 3.35 & 3.32 & 3.34 & 3.34 & 0.986 & N.S & Accept \\
\hline $\begin{array}{l}\text { Transfer of knowledge and experience between } \\
\text { designers }\end{array}$ & 3.29 & 3.18 & 3.45 & 3.32 & 0.382 & N.S & Accept \\
\hline Completeness/contradiction of information & 3.32 & 3.57 & 3.16 & 3.31 & 0.094 & N.S & Accept \\
\hline $\begin{array}{l}\text { Unclear and ambiguous requirements for design } \\
\text { specifications }\end{array}$ & 3.80 & 3.19 & 3.23 & 3.31 & 0.31 & N.S & Accept \\
\hline Authority approval & 2.84 & 3.30 & 3.48 & 3.31 & 0.116 & N.S & Accept \\
\hline Project cost & 3.29 & 3.13 & 3.41 & 3.29 & 0.425 & N.S & Accept \\
\hline Standard of education in contract courses & 3.32 & 3.48 & 3.13 & 3.28 & 0.192 & N.S & Accept \\
\hline Fragmented nature of industry & 3.16 & 3.41 & 3.19 & 3.26 & 0.394 & N.S & Accept \\
\hline Uniqueness of project & 3.32 & 3.24 & 3.20 & 3.23 & 0.915 & N.S & Accept \\
\hline Low designer salary & 3.25 & 3.28 & 3.19 & 3.23 & 0.883 & N.S & Accept \\
\hline Size of project & 3.00 & 3.23 & 3.30 & 3.23 & 0.574 & N.S & Accept \\
\hline Construction start and finish time & 3.29 & 3.19 & 3.22 & 3.22 & 0.932 & N.S & Accept \\
\hline Lack of clarity and legibility & 3.65 & 3.11 & 3.05 & 3.17 & 0.102 & N.S & Accept \\
\hline Inadequate design staff & 3.21 & 3.11 & 3.19 & 3.16 & 0.901 & N.S & Accept \\
\hline Concurrent /overlapping activities & 3.31 & 3.35 & 2.92 & 3.14 & 0.043 & $\mathrm{~S}$ & Reject \\
\hline Amount of work with design organizations & 3.10 & 3.19 & 3.03 & 3.10 & 0.763 & N.S & Accept \\
\hline Personality attitudes & 3.45 & 3.03 & 3.00 & 3.09 & 0.220 & N.S & Accept \\
\hline $\begin{array}{l}\text { Non-request for certificate of insurance covering } \\
\text { design and errors }\end{array}$ & 3.48 & 3.05 & 2.91 & 3.06 & 0.088 & N.S & Accept \\
\hline Type of client & 3.32 & 2.77 & 3.09 & 3.02 & 0.158 & N.S & Accept \\
\hline Acceptance of low design fees & 3.33 & 3.00 & 2.92 & 3.01 & 0.274 & N.S & Accept \\
\hline Re-use of notes and details of similar projects & 3.06 & 2.77 & 3.09 & 3.02 & 0.158 & N.S & Accept \\
\hline
\end{tabular}

Trad=Traditional, $D \& B=$ Design and Build, $P / C$ management $=$ Project/construction management $0.05=$ Significant $=$ Reject Ho, S = Significant, N.S. = Not Significant 
Table 7: Causes of Errors in Contract Documents According to States in South-West, Nigeria

\begin{tabular}{|c|c|c|c|c|c|c|}
\hline Causes of errors & $\begin{array}{l}\text { Ekiti } \\
\text { Mean }\end{array}$ & $\begin{array}{l}\text { Ondo } \\
\text { Mean }\end{array}$ & $\begin{array}{l}\text { Osun } \\
\text { Mean }\end{array}$ & $\begin{array}{l}\text { Oyo } \\
\text { Mean }\end{array}$ & $\begin{array}{l}\text { Ogun } \\
\text { Mean }\end{array}$ & $\begin{array}{l}\text { Lagos } \\
\text { Mean }\end{array}$ \\
\hline Project brief & $2.90(16)$ & $4.40(1)$ & $3.15(36)$ & $3.56(15)$ & $3.69(11)$ & $3.86(1)$ \\
\hline Design management experience & $3.20(9)$ & $3.60(5)$ & $3.85(2)$ & $4.41(2)$ & $4.08(1)$ & $3.84(2)$ \\
\hline Management organizational structure & $3.10(11)$ & $3.83(2)$ & $3.08(40)$ & $3.91(5)$ & $3.25(36)$ & $3.74(3)$ \\
\hline $\begin{array}{l}\text { Poor communication among project } \\
\text { participants }\end{array}$ & $2.50(33)$ & $3.17(20)$ & $3.42(23)$ & $3.64(12)$ & $4.04(2)$ & $3.73(4)$ \\
\hline Physical and mental conditions & $2.90(16)$ & $3.00(25)$ & $3.46(21)$ & $3.22(39)$ & $3.53(20)$ & $3.72(5)$ \\
\hline Lack of coordination between disciplines & $2.90(16)$ & $3.50(7)$ & $3.69(7)$ & $3.25(38)$ & $3.97(3)$ & $3.68(6)$ \\
\hline Carelessness and negligence & $3.10(11)$ & $3.00(24)$ & $3.54(16)$ & $3.28(37)$ & $3.83(8)$ & $3.67(7)$ \\
\hline Lack of design standards & $3.40(2)$ & $3.40(14)$ & $3.77(3)$ & $3.53(22)$ & $3.94(4)$ & $3.66(8)$ \\
\hline Errors in design assumptions/calculations & $3.30(3)$ & $2.20(41)$ & $3.23(32)$ & $3.53(19)$ & $3.89(6)$ & $3.56(9)$ \\
\hline $\begin{array}{l}\text { Availability and contradictions of design } \\
\text { information }\end{array}$ & $2.90(16)$ & $3.20(19)$ & $3.58(11)$ & $3.34(35)$ & $3.77(9)$ & $3.54(10)$ \\
\hline Lack of motivation & $2.70(27)$ & $2.60(33)$ & $3.15(35)$ & $3.47(27)$ & $3.47(24)$ & $3.52(11)$ \\
\hline Lack of awareness of changes in standards & $3.10(11)$ & $3.40(13)$ & $3.38(24)$ & $3.50(24)$ & $3.61(14)$ & $3.49(12)$ \\
\hline $\begin{array}{l}\text { Lack of consistency between drawing and } \\
\text { specification }\end{array}$ & $2.67(28)$ & $3.00(23)$ & $3.75(4)$ & $3.81(8)$ & $3.94(4)$ & $3.49(13)$ \\
\hline Designer professional education & $3.50(1)$ & $3.14(15)$ & $4.15(1)$ & $4.28(3)$ & $3.61(15)$ & $3.49(14)$ \\
\hline Inadequate documentation & $3.20(9)$ & $3.50(6)$ & $3.54(14)$ & $3.47(28)$ & $3.46(25)$ & $3.49(15)$ \\
\hline Identification of project risk & $3.22(8)$ & $2.80(29)$ & $3.31(29)$ & $3.56(16)$ & $3.56(19)$ & $3.48(16)$ \\
\hline Inadequate design time & $2.56(32)$ & $3.00(27)$ & $3.54(17)$ & $3.92(4)$ & $3.27(34)$ & $3.44(17)$ \\
\hline Complexity of design and project & $2.80(22)$ & $3.40(11)$ & $3.69(8)$ & $3.53(23)$ & $3.68(12)$ & $3.40(18)$ \\
\hline Procurement process & $2.80(22)$ & $3.20(18)$ & $3.75(6)$ & $3.16(42)$ & $3.58(16)$ & 3.39 (19) \\
\hline Authority approval & $2.30(39)$ & $2.40(38)$ & $3.33(28)$ & $3.59(13)$ & $3.42(26)$ & $3.37(20)$ \\
\hline Attitude of client & $2.80(22)$ & $3.20(17)$ & $3.00(42)$ & $3.87(6)$ & $3.11(41)$ & $3.36(21)$ \\
\hline Lack of planning and inspection of project & $2.90(16)$ & $2.60(31)$ & $3.17(34)$ & $3.59(14)$ & $3.56(17)$ & $3.35(22)$ \\
\hline Unrealistic client demand & $2.67(28)$ & $3.75(4)$ & $3.15(37)$ & $3.53(21)$ & $3.40(29)$ & $3.34(23)$ \\
\hline Insufficient fund to create quality documents & $2.10(43)$ & $2.80(28)$ & $3.23(33)$ & $4.47(1)$ & $3.86(7)$ & $3.33(24)$ \\
\hline $\begin{array}{l}\text { Unclear and ambiguous requirements for } \\
\text { design specifications }\end{array}$ & $2.40(37)$ & $2.60(30)$ & $3.08(39)$ & $3.66(11)$ & $3.56(18)$ & $3.30(25)$ \\
\hline $\begin{array}{l}\text { Transfer of knowledge and experience } \\
\text { between designers }\end{array}$ & $3.30(3)$ & $3.00(26)$ & $3.54(15)$ & $3.20(40)$ & $3.53(21)$ & $3.29(26)$ \\
\hline Fragment nature of industry & $2.50(33)$ & $3.40(8)$ & $3.75(5)$ & $3.47(25)$ & $3.03(42)$ & $3.28(27)$ \\
\hline Amount of work with design organizations & $2.50(33)$ & $1.80(43)$ & $3.25(31)$ & $3.16(41)$ & $3.14(39)$ & $3.28(28)$ \\
\hline Nature of economy & $3.00(14)$ & $3.40(9)$ & $3.58(10)$ & $3.56(17)$ & $3.36(31)$ & $3.26(29)$ \\
\hline Project cost & $3.30(3)$ & $3.80(3)$ & $3.58(12)$ & $3.31(36)$ & $3.14(38)$ & $3.25(30)$ \\
\hline Uniqueness of project & $3.30(3)$ & $3.20(16)$ & $3.42(22)$ & $2.84(43)$ & $3.50(22)$ & $3.24(31)$ \\
\hline $\begin{array}{l}\text { Standard of university education in } \\
\text { construction courses }\end{array}$ & $3.25(6)$ & $3.00(21)$ & $3.50(18)$ & $3.45(29)$ & $3.25(37)$ & $3.23(32)$ \\
\hline Type of client & $2.30(39)$ & $3.40(10)$ & $2.67(44)$ & $3.38(33)$ & $2.50(44)$ & $3.22(33)$ \\
\hline Construction start and finish time & $2.30(39)$ & $2.60(32)$ & $2.77(43)$ & $3.87(7)$ & $3.33(33)$ & $3.19(34)$ \\
\hline Completeness/contradiction of information & $2.67(28)$ & $2.40(39)$ & $3.25(30)$ & $3.77(9)$ & $3.69(10)$ & $3.15(35)$ \\
\hline Size of project & $2.60(31)$ & $3.00(22)$ & $3.46(20)$ & $3.56(18)$ & $3.25(35)$ & $3.15(36)$ \\
\hline Low designer salary & $3.00(14)$ & $1.75(44)$ & $3.50(19)$ & $3.69(10)$ & $3.42(28)$ & $3.09(37)$ \\
\hline $\begin{array}{l}\text { Non-request for certificate of insurance } \\
\text { covering design and errors }\end{array}$ & $2.20(42)$ & $3.40(12)$ & $3.15(38)$ & $2.81(44)$ & $3.33(32)$ & $3.08(38)$ \\
\hline Inadequate design staff & $2.90(16)$ & $2.50(35)$ & $3.38(26)$ & $3.34(34)$ & $3.40(30)$ & $3.05(39)$ \\
\hline Concurrent /overlapping activities & $2.50(33)$ & $2.50(34)$ & $3.38(25)$ & $3.41(32)$ & $3.42(27)$ & $3.00(40)$ \\
\hline Personality attitudes & $2.80(22)$ & $2.40(36)$ & $3.54(13)$ & $3.42(31)$ & $3.14(40)$ & $2.99(41)$ \\
\hline Lack of clarity and legibility & $2.33(38)$ & $2.40(37)$ & $3.38(27)$ & $3.47(26)$ & $3.67(13)$ & $2.99(42)$ \\
\hline $\begin{array}{l}\text { Re-use of notes and details of similar } \\
\text { projects }\end{array}$ & $2.00(44)$ & $3.20(40)$ & $3.00(41)$ & $3.53(20)$ & $2.69(43)$ & $2.82(43)$ \\
\hline Acceptance of low design fees & $2.78(26)$ & $3.20(42)$ & $3.62(9)$ & $3.44(30)$ & $3.50(23)$ & $2.64(44)$ \\
\hline
\end{tabular}

The factors with the highest contribution to errors in contract documents (total) based on procurement methods are design management experience (3.94), project brief (3.70), designers' professional education (3.70), lack of design standards (3.67), poor communication among project participants (3.63), lack of coordination among disciplines (3.61), management organisational structure (3.60), carelessness and negligence (3.55) and insufficient fund to create quality documents (3.53) among others. The ANOVA test conducted shows that only inadequate documentation and concurrent/overlapping activities are significantly different within the forty-four (44) causes of 
errors in contract documents investigated based on procurement method. The implication of this result is that procurement option will only cause an error when the contract documents are incomplete, and designers do activities concurrently. Contract documents could only be incomplete in design and build option and the traditional method. This could mean that the traditional and design and build methods are more prone to errors that the management method. This could also explain the reason why the industry professionals are campaigning that the management practices should be embraced above other methods.

Table 8: Difference in the Causes of Errors in Contract Documents among the South-Western States

\begin{tabular}{|c|c|c|c|c|c|}
\hline Causes of errors & F cal & Df & $\begin{array}{c}\mathbf{P} \\
\text { Value }\end{array}$ & Sig. & Decision \\
\hline Management organizational structure & 1.851 & 183 & 0.105 & N. significant & Accept $\mathrm{H}_{\mathrm{o}}$ \\
\hline Project brief & 2.546 & 183 & 0.030 & Significant & Reject $\mathrm{H}_{\mathrm{o}}$ \\
\hline Lack of coordination between disciplines & 1.579 & 183 & 0.168 & N. significant & Accept $\mathrm{H}_{\mathrm{o}}$ \\
\hline Poor communication among project participants & 1.903 & 183 & 0.097 & N. significant & Accept $\mathrm{H}_{\mathrm{o}}$ \\
\hline Design management experience & 1.746 & 183 & 0.126 & N. significant & Accept $\mathrm{H}_{\mathrm{o}}$ \\
\hline Designer professional education & 2.762 & 183 & 0.020 & Significant & Reject $\mathrm{H}_{\mathrm{o}}$ \\
\hline Acceptance of low design fees & 6.194 & 183 & 0.000 & Significant & Reject $\mathrm{H}_{\mathrm{o}}$ \\
\hline Inadequate design time & 2.542 & 183 & 0.030 & Significant & Reject $\mathrm{H}_{\mathrm{o}}$ \\
\hline Low designer salary & 4.519 & 183 & 0.001 & Significant & Reject $\mathrm{H}_{\mathrm{o}}$ \\
\hline Inadequate design staff & 1.475 & 183 & 0.201 & N. significant & Accept $\mathrm{H}_{\mathrm{o}}$ \\
\hline Concurrent /overlapping activities & 2.453 & 183 & 0.036 & Significant & Reject $\mathrm{H}_{\mathrm{o}}$ \\
\hline Amount of work with design organization & 2.974 & 183 & 0.013 & Significant & Reject $\mathrm{H}_{\mathrm{o}}$ \\
\hline Availability and contradictions of design information & 1.140 & 183 & 0.341 & N. significant & Accept $\mathrm{H}_{\mathrm{o}}$ \\
\hline Transfer of knowledge and experience between designers & 0.548 & 183 & 0.739 & N. significant & Accept $\mathrm{H}_{\mathrm{o}}$ \\
\hline Physical and mental conditions & 1.735 & 183 & 0.129 & N. significant & Accept $\mathrm{H}_{\mathrm{o}}$ \\
\hline Lack of motivation & 1.889 & 183 & 0.097 & N. significant & Accept $\mathrm{H}_{\mathrm{o}}$ \\
\hline Carelessness and negligence & 1.364 & 183 & 0.240 & N. significant & Accept $\mathrm{H}_{\mathrm{o}}$ \\
\hline Lack of design standards & 0.583 & 183 & 0.713 & N. significant & Accept $\mathrm{H}_{\mathrm{o}}$ \\
\hline Lack of awareness of changes in standards & 0.266 & 183 & 0.931 & N. significant & Accept $\mathrm{H}_{\mathrm{o}}$ \\
\hline Unrealistic client demand & 0.955 & 183 & 0.447 & N. significant & Accept $\mathrm{H}_{\mathrm{o}}$ \\
\hline Inadequate documentation & 0.122 & 183 & 0.987 & N. significant & Accept $\mathrm{H}_{\mathrm{o}}$ \\
\hline Errors in design assumptions/calculation & 2.639 & 183 & 0.025 & Significant & Reject $\mathrm{H}_{\mathrm{o}}$ \\
\hline Lack of consistency between drawing and specifications & 1.961 & 183 & 0.087 & N. significant & Accept $\mathrm{H}_{\mathrm{o}}$ \\
\hline Lack of clarity and legibility & 3.090 & 183 & 0.011 & Significant & Reject $\mathrm{H}_{\mathrm{o}}$ \\
\hline Personality attitudes & 1.555 & 183 & 0.175 & N. significant & Accept $\mathrm{H}_{\mathrm{o}}$ \\
\hline Re-use of notes and details of similar projects & 3.395 & 183 & 0.006 & Significant & Reject $\mathrm{H}_{\mathrm{o}}$ \\
\hline Type of client & 2.742 & 183 & 0.021 & Significant & Reject $\mathrm{H}_{\mathrm{o}}$ \\
\hline Contract start and finish time & 3.971 & 183 & 0.002 & Significant & Reject $\mathrm{H}_{\mathrm{o}}$ \\
\hline Lack of planning and inspection of project & 1.543 & 183 & 0.179 & N. significant & Accept $\mathrm{H}_{\mathrm{o}}$ \\
\hline Identification of project risk & 0.800 & 183 & 0.551 & N. significant & Accept $\mathrm{H}_{\mathrm{o}}$ \\
\hline Attitude of client & 2.342 & 183 & 0.043 & Significant & Reject $\mathrm{H}_{\mathrm{o}}$ \\
\hline Insufficient fund to create quality documents & 8.139 & 183 & 0.000 & Significant & Reject $\mathrm{H}_{\mathrm{o}}$ \\
\hline $\begin{array}{l}\text { Non-request for certificate of insurance covering design and } \\
\text { errors }\end{array}$ & 1.740 & 183 & 0.128 & N. significant & Accept $\mathrm{H}_{\mathrm{o}}$ \\
\hline $\begin{array}{l}\text { Unclear and ambiguous requirements for design } \\
\text { specifications }\end{array}$ & 3.393 & 183 & 0.006 & Significant & Reject $\mathrm{H}_{\mathrm{o}}$ \\
\hline Completeness/contradiction of information & 4.505 & 183 & 0.001 & Significant & Reject $\mathrm{H}_{\mathrm{o}}$ \\
\hline Uniqueness of project & 0.780 & 183 & 0.566 & N. significant & Accept $\mathrm{H}_{\mathrm{o}}$ \\
\hline Project cost & 0.527 & 183 & 0.756 & N. significant & Accept $\mathrm{H}_{\mathrm{o}}$ \\
\hline Procurement process & 1.045 & 183 & 0.393 & N. significant & Accept $\mathrm{H}_{\mathrm{o}}$ \\
\hline Size of project & 1.014 & 183 & 0.411 & N. significant & Accept $\mathrm{H}_{\mathrm{o}}$ \\
\hline Authority approval & 2.083 & 183 & 0.070 & N. significant & Accept $\mathrm{H}_{\mathrm{o}}$ \\
\hline Complexity of design and project & 0.724 & 183 & 0.606 & N. significant & Accept $\mathrm{H}_{\mathrm{o}}$ \\
\hline Nature of economy & 0.500 & 183 & 0.776 & N. significant & Accept $\mathrm{H}_{\mathrm{o}}$ \\
\hline Standard of university education in contract courses & 0.367 & 183 & 0.871 & N. significant & Accept $\mathrm{H}_{\mathrm{o}}$ \\
\hline Fragment nature of industry & 2.215 & 183 & 0.055 & N. significant & Accept $\mathrm{H}_{\mathrm{o}}$ \\
\hline
\end{tabular}

$<0.05$ = Significant, therefore Accept Ho

Table 7 indicates the causes of errors in contract documents based on the states in South-West, Nigeria. Under each state, the mean scores for the investigated variables were recorded with their ranks enclosed in brackets. In Ekiti state, the leading causes of errors in contract documents are designers' professional education 
(3.50), lack of design standards (3.40), transfer of knowledge and experience (3.53) among designers. The leading causes of errors in Ondo State are - project brief (4.40), management organisational structure (3.82), project cost (3.80) and unrealistic client demand (3.75). The top causes of errors in Osun State are designer, professional education (4.15), design management experience (3.85), lack of design standard and lack of consistency between drawings (3.77) and specifications (3.75). In Oyo state, the leading causes of errors in contract documents are insufficient fund to create quality documents (4.47), design management experience (4.41), designers' professional education (4.28) and inadequate design time (3.92). In Ogun state, the top causes of errors in contract documents are design management experience (4.08), poor communication among project participants (4.04), lack of coordination among disciplines (3.97), lack of consistency between drawings and specifications
(3.94), lack of design standards (3.94) and errors in assumptions/calculations (3.89). In Lagos State, the causes of errors in contract documents are - project brief (3.86), design management experience (3.84), management organisational structure (3.74), poor communication among project participants (3.73), physical and mental condition (3.72) among others. The implication of this analysis is that the causes of errors in contract documents vary from one state to the other. The reason for this variation is not investigated in this study.

Table 8 shows the difference in the causes of errors in contract documents among the South West states in Nigeria. The test shows that out of the 44 causes investigated in this study, there are no significant differences in 27 of them. This indicates that there are significant differences in 17 of the causes of errors investigated.

Table 9: Frequency of the Causes of Error in Contract Documents

\begin{tabular}{lcc}
\hline \multicolumn{1}{c}{ Causes of errors in contract documents } & $\begin{array}{c}\text { Frequency of } \\
\text { occurrence }\end{array}$ & Percentage \\
\hline Frequent design changes by client & 23 & 22.1 \\
Lack of adequate time to prepare contract documents & 18 & 17.3 \\
Oversight, negligence and laziness & 8 & 7.7 \\
Lack of concentration/ review of contract documents & 2 & 2.0 \\
Use of inexperience designers to prepare contract documents & 11 & 10.6 \\
Lack of proper understanding of clients' brief and designers' specifications & 5 & 4.8 \\
Poor design fee/supervision fee/poor salary to professional staff of designers' & 6 & 5.8 \\
organizations & 5 & 4.8 \\
Unprofessionalism (lack of site visitation) & 3 & 2.9 \\
Lack of adequate communication & 5 & 4.8 \\
Incomplete document at the time of tender/finalizing contract (use of provisional sums & 5 & 4.8 \\
to cover many work items) & 5 & 4.8 \\
Lack of design coordination & 5 & 3.8 \\
Omission, conflicting documentation and lack of detailed drawing & 4 & 3.8 \\
Poor design documentation/lack of quality focus & 4 & $\mathbf{1 0 0}$ \\
Poor supervision by consultants as a result of inexperience and & $\mathbf{1 0 4}$ & \\
Unprofessionalism & & \\
Total number of occurrences & &
\end{tabular}

This result was quite expected as many of the studies (Mohammed, 2007, Barkow, 2005, Long, 2011) on design errors shows that the causes of errors in contract documents vary from country to country and location to location. This finding only empirically confirmed the assertions.

The interview of contractors, consultants and project managers on 51 building projects as shown in Table 9 indicates that the frequent causes of errors in contract documents are frequent design changes by client $(22.1 \%)$, lack of adequate time to prepare contract documents $(17.3 \%)$, use of inexperienced designers to prepare documents (10.6\%) and oversight, negligence and carelessness (7.7\%). It is important to note that there is an agreement between the interview and questionnaire survey because in both cases, the frequent causes of errors in contract documents are similar. Frequent design changes by clients will send designers back to the drawing board, and the quantity surveyors will also have to prepare the bills of quantities again. When this process occurs frequently, it can lead to a mix-up and depression in some cases. Lack of adequate design time will prompt designers to take short cuts thereby violating rules and procedures of contract documentation which can cause errors.

During the interview session, a respondent discussed that on a particular project, the client got dissatisfied with the agreement signed with the contractor; therefore, the client claimed that it was an error from the designers and as such, he wanted a redesign of documents which led to conflicting documents and delay on the project. Next, to clients changing of design and specifications, $17.3 \%$ emphasized that client's put so much pressure on designers during the preparation of contract documents; therefore, the designers become susceptible to errors. Third on the table is the use of inexperienced designers $(10.6 \%)$ such as Industrial Training (IT) students and nonpracticing professionals. The fourth cause identified is the oversight by professionals, negligence and laziness $(7.7 \%)$. This is followed by payment of poor design/supervision fee to designers' organization which 
also leads to payment of poor salary to the professional staff of designer's organizations. Unprofessionalism such as lack of visitation to site before the design is done is rated $4.8 \%$.

Improper and incomplete contract documentation at the time of tender/finalizing the contract; omission, conflicting documents and undetailed drawings, lack of proper/inadequate understanding of clients' brief and designers specification and lack of design coordination all have a representation of $4.8 \%$. The findings of the study were buttressed by interviews which indicate that clients' frequent change of designs and specifications, lack of adequate time to prepare contract documents, use of inexperienced designers, oversight, negligence and laziness are the most frequent causes of errors in contract documents. This result agrees with Barkow (2005), Mohammed (2007), Palaneeswaran et al (2007) and Vrouwenvelder et al (2009) who noted that carelessness, negligence, acceptance of poor design fee, client change of design and specifications, type of client, poor communication, lack of adequate documentation and lack of coordination among disciplines are the major causes of errors in contract documents.

\section{Conclusion}

Based on the findings of this study, it was concluded that errors in contract documents are frequently caused by clients' change of design and specifications, lack of adequate time to prepare contract documents, use of inexperienced designers to prepare contract documents, oversight, negligence and laziness. Also, there is a significant difference in the causes of errors in contract documents between contractors and consultants. There is also a significant difference in the causes of errors in contract documents from one state to the other in SouthWest, Nigeria. This means that the causes of errors in contract documents are different across the construction industries of various countries and Nigeria is not an exception. The study also concludes that there is a significant difference in the causes of errors in contract documents based on the type of project. Furthermore, based on procurement method, the study concludes that inadequate contract documentation and concurrent/ overlapping activities are the causes of errors in contract documents

\section{References}

Ade-Ojo, C.O. and Babalola, A.A. 2013. Cost and time performance of contract projects under the due process reforms in Nigeria. Research Invent: International Journal of Engineering and Science, 3(6): 1-6

Alarcon, L. F. and Mardones, D. A. 1998. Improving the design contract interface In the Proceedings of International Group for Lean Construction (IGLC), Sao Paulo

Babalola, J.A. and Idehen, A.F. 2011. Causes of variation on building projects in Nigeria. In: Laryea, S., Leiringer, R. \& Hughes, W. (Eds) Proceedings of West Africa Built Environment Research (WABER) Conference, 19-21 July 2011, Accra, Ghana, 229-236
Based on the conclusions, the study recommends that the frequent causes of errors in contract documents which include lack of adequate time to prepare documents, oversight, negligence and laziness, use of inexperienced designers and lack of proper understanding of clients brief must be prevented to minimize cost and time overrun of building projects to the barest minimum. In Nigeria, it is evident from the inferential statistics that the causes of errors in contract documents vary from one state to the other. Therefore, it is recommended that consultants practising in Nigeria will consider the frequent causes identified in this study as the ones to avoid when preparing contract documents for building projects. The causes established in this study particularly are mostly related to the consultants and designers. Therefore, to prevent them, there is need to introduce quality assurance measures in consulting organizations. One of the ways this measure can be introduced is the engagement of the services of professional builders by construction clients into the design team to conduct buildability and maintainability analysis of building projects and then prepares a report on it. This has been the clamour of professional bodies in Nigeria, particularly the Nigerian Institute of Building (NIOB). If this step is not taken, it may be difficult to prevent the occurrence of errors in contract documents. Buildability and maintainability analysis is a core function of professional builders according to the NBC (2006), but it has not been implemented because the code is yet to be passed into law by the national assembly. Therefore, the government of the Federal Republic of Nigeria need to rise and help the construction industry combat the menace of cost and time overrun by passing the National Building Code into law. Also, for every contract document that is prepared, there must be a senior consultant or designer to check and sign the document as a way of accepting responsibility for any error discovered on the document.

\section{ACKNOWLEDGEMENT}

I acknowledge the financial support of the Tertiary Education Trust Fund (TETFUND) of Nigeria towards the execution of this work.

Barkow, B. 2005. Human factors underlying building failures. National Research Council of Canada, Toronto, Ontario

Buratti, J. L. Farrington, J. J. and Ledbetter, W. B. 1992. Causes of quality deviations in design and contract. Journal of Contract Engineering and Management, 118(1), 34-49

Cheng-Wing, S.L. and Davey, E.C. 1998. Designing to avoid human error consequences. (Online). www.dcs.gla.ac.uk (24th September, 2011)

Choy, W.K. and Sidwell, A.C. 1991. Bills of Quantities continued - Sources of variations in Australian contract contracts. Building Economist, 30 (3): 25-30

Diekmann. J.E. and Nelson, M.C. 1985. Contract claims: Frequency and severity. Journal of Contract Engineering \& Management, 111 (1): 74-81 
Dosumu, O.S. and Adenuga, O.A. 2013. Causes, effects and remedies of errors in Nigerian construction documents. Organization, Technology and Management in Construction, University of Zagreb, Croatia, 5 (1): 676686

Dosumu, O. S. and Iyagba, R. A. 2013. An appraisal of factors responsible for errors in Nigerian construction documents. Ethiopian Journal of Environmental Studies and Management, Bahir Dar University, Ethiopia, 6 (1): 49-57

Endsley, M.R. 1999, Situation awareness and human error: Designing to support human performance. In Proceedings of the High Consequence Systems Surety Conference, Albuquerque, NM,

Love, P.E., Davis, P., London, K. and Jasper, T. 2008. Causal modelling of construction disputes. In Proceedings of 24th Annual ARCOM Conference, 1st - 3rd September, 869-878

Love, P.E., Edwards, D.J., Han, S. and Goh, Y.M. 2011. Design error reduction: towards the effective utilization of building information modelling, Research in Engineering Design, 22, 173-187

Mohammed, R.E. 2007. 'An exploratory system dynamics model to investigate the relationships between errors that occur in contract documents in Saudi Arabia and their possible causes'. An unpublished $\mathrm{PhD}$ thesis submitted to Heriot-Watt University School of the Built Environment

Mukaka, M.J., Aigbavboa, C.O. and Thwala, W.D. 2014. A theoretical review of the causes and effects of contract projects cost \& schedule overrun. Paper presented at the International Conference on Emerging Trend in Computer and Image Processing on 15-16 December 2014 at Pattaya, Thailand

National Building Code. 2006. Federal Republic of Nigeria National Building Code. Lexis Nexis Butterworks, South Africa
Norman, D.A. 1983. Design rules based on analyses of human error. Communications of the ACM, 4 (26); 254258

Okuntade, T.F. 2014. Effects of faulty contract on building maintenance. International Journal of Technology Enhancements and Emerging Engineering Research 2(3): 73-79

Olaniyan, O.A. 2011. Designing out waste on mass housing contract sites in Minna, Niger state. In: Laryea, S., Leiringer, R. \& Hughes, W. (Eds) Proceedings of West Africa Built Environment Research (WABER) Conference, 19-21 July 2011, Accra, Ghana, 315-323

Ortega, I. and Bisgaard, S. 2000. Quality improvement in the construction industry; three systematic approach. Total Quality Management, 11(4): 383-392

Palaneeswaran, E., Ramanathan, M. and Tam, C. 2007. Rework in projects: Learning from errors. Surveying and Built Environment, 18(2): 47-58.

Rooney, J.J., Heuvel, L.N. and Lorenzo, D.K. 2002. Reduce human error. Quality Progress, 27-36

Shelton, C.P. 1999. Human interface/human error. (Online): www.users.ece.cmu.edu (12th September 2012)

Tilley, P.A., Mcfallan, S.L. and Tucker, S.N. 2005. "Design and Documentation Quality and its Impact on the Contract Process". CIB W55 \& W65 Joint Triennial Symposium, Cape Town.

Tzortzopoulos, P. and Formoso, C. T. 1999. Considerations on application of lean construction principles to design management. In Proceedings of IGLC, 7, 26-28.

Vrouwenvelder, T., Holicky, M. and Sykora, M. 2009, Modelling of Human Error. Joint Workshop of COST Actions, Ljubljana, Slovenia, 21-22 September 2009, 5564

Yates, J. K., and Lockley, E. E. 2002. "Documenting and analyzing contract failures." Journal of Contract Engineering and Management, 128(1): 8-17. 